\title{
Oxygen and the Growth and Metabolism of Clostridium acetobutylicum
}

\author{
By R. W. O'BRIEN* AND J. G. MORRIS $\dagger$ \\ Department of Biochemistry, School of Biological Sciences, \\ University of Leicester, Leicester, $L E$ I $7 R H$
}

(Accepted for publication 26 July 1971)

\begin{abstract}
SUMMARY
Clostridium acetobutylicum has been studied during batch cultivation at $\mathrm{pH} 7$ and $35^{\circ}$ in a glucose + casein hydrolysate + vitamins and salts medium kept (i) anaerobic $\left(E_{\mathrm{h}},-400\right.$ to $\left.-370 \mathrm{mV}\right)$, (ii) aerated $\left(E_{\mathrm{h}},-50\right.$ to $0 \mathrm{mV}$; dissolved $\left.\mathrm{O}_{2},<\mathrm{I} \mu \mathrm{M}\right)$, and (iii) aerobic $\left(E_{\mathrm{h}},+100 \mathrm{mV}\right.$; dissolved $\mathrm{O}_{2}, 40$ to $\left.50 \mu \mathrm{M}\right)$. Shortterm ( 4 to 6 h.) exposure to oxygen was not lethal, though at sufficiently high concentrations oxygen decreased the rate of glucose consumption, halted growth and prevented net synthesis of DNA, RNA and protein. Under these aerobic conditions the organism was drained of 'reducing power' and starved of energy - as evidenced by cessation of butyrate formation (but not of acetate production), and by a marked fall in intracellular ATP. These consequences of oxygenation were swiftly reversed when anaerobic conditions were re-established; 'normal' growth and glucose metabolism then resumed. There was no evidence of $\mathrm{H}_{2} \mathrm{O}_{2}$ production, nor could the effects of oxygenation be attributed merely to its elevation of the culture $E_{\mathrm{h}}$. Thus oxygen $(40 \mu \mathrm{M})$ inhibited growth even in a medium poised with dithiothreitol at $-50 \mathrm{mV}$, while growth and glucose metabolism continued unchecked when the $E_{\mathrm{h}}$ of an anaerobic culture was maintained at $+370 \mathrm{mV}$ by addition of potassium ferricyanide.
\end{abstract}

\section{INTRODUCTION}

Since Pasteur (I86I) reported the existence of obligately anaerobic bacteria, considerable effort has been expended in the search for the prime cause of the toxicity of oxygen to these organisms. Four main hypotheses have been proposed at various times. (I) Oxygen itself is the toxic agent and is invariably lethal to the organism. (2) Anaerobes only flourish in media of low $E_{\mathrm{h}}$ (usually of the order of $-\mathrm{I} 50$ to $-400 \mathrm{mV}$ at $\mathrm{pH} 7$ ) and in the presence of free $\mathrm{O}_{2}$ this low redox potential could neither be attained nor maintained. (3) An organism which lacks catalase, e.g. a species of Clostridium, is poisoned by the $\mathrm{H}_{2} \mathrm{O}_{2}$ which it forms when reducing some of the supplied oxygen. (4) Oxygen is so much more avid an electron acceptor than the normal terminal oxidants of fermentation, that with oxygen present the anaerobe is unable to maintain the intracellular concentrations of electron donors such as $\mathrm{NAD}(\mathrm{P}) \mathrm{H}$ that are required for biosynthesis and growth. Each of these hypotheses has had its proponents and detractors but none has as yet emerged as a unitary explanation of obligate anaerobiosis (for a more comprehensive review see Morris \& O'Brien, I97I).

Because exponentially growing cultures of Clostridium acetobutylicum could tolerate short exposure to relatively high concentrations of oxygen and make an apparently complete recovery, we hoped that study of the interaction of this organism with oxygen would enable us to test some of the hypotheses listed above.

\footnotetext{
* Present address: Department of Biochemistry, University of Sydney, Sydney, N.S.W., Australia.

$\uparrow$ Present address: Department of Botany and Microbiology, University College of Wales, Aberystwyth.
} 


\section{METHODS}

Organism. Clostridium acetobutylicum NCIB 8052 was maintained as a spore culture on cooked meat medium; these spores could be germinated when required, by heat shocking at $80^{\circ}$ for $5 \mathrm{~min}$. The organism was carried through ten vegetative transfers and then a fresh spore inoculum was activated.

Medium. The basal growth medium contained (per 1.): glucose, Io g.; $\mathrm{MgSO}_{4} \cdot 7 \mathrm{H}_{2} \mathrm{O}$, 0.2 g.; $\mathrm{MnSO}_{4} .4 \mathrm{H}_{2} \mathrm{O}$, 0.0I g.; $\mathrm{FeSO}_{4} .7 \mathrm{H}_{2} \mathrm{O}$, 0.0I g.; $p$-aminobenzoic acid, I mg.; biotin, $2 \mu \mathrm{g}$.; thiamine. $\mathrm{HCl}, \mathrm{I} \mathrm{mg}$.; casein hydrolysate (Oxoid), $4 \mathrm{~g}$. It was sterilized by autoclaving at ${ }_{5} 5 \mathrm{lb}$./in ${ }^{2}$. for ${ }_{5} 5 \mathrm{~min}$., and $\mathrm{K}_{2} \mathrm{HPO}_{4}$ plus $\mathrm{KH}_{2} \mathrm{PO}_{4}$ were then added aseptically from sterile solutions each to final concentrations of $0.5 \mathrm{~g}$./1. which brought the final $\mathrm{pH}$ value to 6.9 .

Growth. Cultures were grown in a pyrex glass culture vessel with a $400 \mathrm{ml}$. inner growth chamber whose contents were continuously mixed by a magnetic stirrer and maintained at $35^{\circ}$ by warmed water circulated through an outer jacket. The vessel was sealed with a rubber bung carrying a combined glass and calomel electrode (Radiometer, Copenhagen, Denmark; type GK 202) plus a platinum electrode ( $26 \mathrm{~s}$.w.g. Pt wire spiral) which was used with the calomel electrode of GK 202 for $E_{\mathrm{h}}$ measurement. Gas mixtures could be passed through or over the culture, and two side ports were provided (i) for the insertion of an oxygen electrode (Yellow Springs Instrument Co., Ohio, U.S.A.; model 4004), and (ii) for the removal of samples of culture. The concentration of dissolved oxygen was recorded on a Heath-Built Servo Recorder (Heath (Gloucester) Ltd; Model EUW-20A) and the $E_{\mathrm{h}}$ and $\mathrm{pH}$ of the culture were measured with a Radiometer $\mathrm{pH}$ meter (Model 25). The growth chamber in the culture vessel was sterilized by overnight treatment with alkaline sodium hypochlorite, and before use was thoroughly washed with sterile water. The electrodes were similarly treated (but with shorter exposure to hypochlorite).

Sterile medium ( $350 \mathrm{ml}$.) in the culture vessel was sparged for Io min. with sterile argon to remove the last traces of dissolved oxygen. After inoculating with $50 \mathrm{ml}$. of a $16 \mathrm{~h}$. culture growing anaerobically in the same medium, the head space was flushed with argon and the culture (at $35^{\circ}$ ) was maintained at $\mathrm{pH} 6.8$ to 7.2 by the intermittent addition of sterile $\mathrm{K}_{2} \mathrm{CO}_{3}(60 \%$, w/v). Growth was followed turbidimetrically at $680 \mathrm{~nm}$.; the dry wt organisms/ $\mathrm{ml}$. culture was then found from a calibration curve. Samples of culture were filtered through Millipore membranes $(0.8 \mu \mathrm{m}$. pore $)$ and the filtrates were stored at $-\mathrm{I} 5^{\circ}$ until analysed for their contents of glucose, pyruvate, acetate and butyrate.

Preparation of extracts. The organisms from $350 \mathrm{ml}$. of culture (approx. $280 \mathrm{mg}$. dry wt) were harvested by centrifuging at $12,000 \mathrm{~g}$ for $20 \mathrm{~min}$. at $2^{\circ}$, and were stored at $-15^{\circ}$ for $15 \mathrm{~h}$. The pellet was thawed in Io to $15 \mathrm{ml}$. of $20 \mathrm{mM}$-potassium phosphate buffer, $\mathrm{pH} 7$, and the organisms were ruptured by passage of the suspension through a chilled French pressure cell (Aminco, Inc., Silver Spring, Maryland, U.S.A.) at I 2,000 lb./in. ${ }^{2}$. Debris was removed from the extract by centrifuging at $25,000 \mathrm{~g}$ for $15 \mathrm{~min}$. at $5^{\circ}$.

\section{Assay procedures}

Glucose. Glucose was assayed colorimetrically by the standard 'Glucostat' procedure (Teller, 1956). The glucose content of whole organisms was determined after acid hydrolysis. Organisms harvested by centrifuging Io $\mathrm{ml}$. samples of culture, were twice washed with Io $\mathrm{ml}$. vol. of $\mathrm{o} \cdot \mathrm{I}$ M-potassium phosphate buffer, $\mathrm{pH} 7$. They were then resuspended in Io $\mathrm{ml}$. of $2 \mathrm{~N}$-sulphuric acid and heated at $100^{\circ}$ for $3 \mathrm{~h}$. The hydrolysate was neutralized with ION$\mathrm{NaOH}$, diluted to a measured volume, and its glucose content assayed.

Acetate and butyrate. The acetate and butyrate contents of culture filtrates were measured 
by gas-liquid chromatography using a Pye Series I04 Chromatograph (Pye Unicam Ltd, Cambridge) with flame ionization detectors. A $5 \mathrm{ft}$ glass column was used, containing $10 \%$ diethylene glycol adipate with $2 \%$ phosphoric acid on $100 / 200$ mesh celite. Samples (10 $\mu 1$.) acidified with phosphoric acid were directly chromatographed at $125^{\circ}$ using $\mathrm{N}_{2}$ as carrier gas at a flow rate of $50 \mathrm{ml} . / \mathrm{min}$.

Pyruvate. Pyruvate in culture filtrates was assayed spectrophotometrically at $340 \mathrm{~nm}$. by measuring the extent of oxidation of NADH in the presence of excess lactate dehydrogenase, E.C. I I . I . 27 (Bucher, Czok, Lamprecht \& Latzko, 1965).

$A T P$ and $A D P$. The ATP content of organisms was measured by the luciferin-luciferase method (Stanley \& Williams, I 969) after immediate extraction into $0.3 \mathrm{M}-\mathrm{H}_{2} \mathrm{SO}_{4}$ (Forrest \& Walker, 1965). ADP was similarly assayed after quantitative conversion to ATP by a mixture of creatine phosphate plus creatine kinase EC 2.7.3.2 (Sunderland \& Merrett, I967).

$D N A$ and RNA. DNA was measured by the diphenylamine procedure of Burton (1956), while RNA was determined using the orcinol method of Schneider (I957).

Protein. Protein was assayed by the biuret method of Gornall, Bardawill \& David (1949).

$N A D H$ oxidase. The NADH oxidase activity of bacterial extracts was assayed spectrophotometrically at $340 \mathrm{~nm}$. by following the aerobic rate of disappearance of NADH. Silica cuvettes ( $1 \mathrm{~cm}$. light path) contained in I ml. final vol.: tris- $\mathrm{HCl}$ buffer, $\mathrm{pH} 7,100 \mu$ moles; NADH, $0 . \mathrm{I} \mu$ mole; bacterial extract, 0.03 to $0.2 \mathrm{mg}$. protein. The 'blank' cuvette contained the above system minus NADH. Assuming $E_{340}$ of $\mathrm{NADH}$ to be $6.2 \times 10^{3} \mathrm{M}^{-1}$ $\mathrm{cm} .^{-1}$, the specific activity of the enzyme was calculated as $\mu$ mole NADH oxidized $/ \mathrm{h} . / \mathrm{mg}$. of protein.

Other materials. $N, N, N^{\prime}, N^{\prime}$-Tetramethylazoformamide (i.e. 'diamide') was synthesized by the method of Crawford \& Raap (1963), while metronidazole was a gift from May and Baker, Ltd, Dagenham, Essex. Casein acid hydrolysate and cooked meat medium were purchased from Oxoid, Ltd, London. Lactic dehydrogenase and NADH were obtained from The Boehringer Corporation (London) Ltd, and crystalline (beef liver) catalase, creatine phosphate and creatine kinase were supplied by Sigma Chemical Co. Ltd, London.

\section{Effects of changes in culture $E_{\mathrm{h}}$}

\section{RESULTS}

During anaerobic growth of Clostridium acetobutylicum in the glucose + casein hydrolysate basal medium, the culture $E_{\mathrm{h}}$ was in the range -250 to $-400 \mathrm{mV}$. These reducing conditions were very rapidly established by the inoculum if the medium was first made anaerobic by flushing with argon. If air was subsequently sparged through the growing culture, the $E_{\mathrm{h}}$ rapidly rose from $-400 \mathrm{mV}$ to approximately $+120 \mathrm{mV}$, at which $E_{\mathrm{h}}$ the dissolved oxygen concentration was sufficiently high to be detected by the polarographic oxygen electrode (Methods). Any further increase in $\mathrm{O}_{2}$ concentration had little additional effect on the culture $E_{\mathrm{h}}$. Under these aerobic conditions $\left(E_{\mathrm{h}}=+100 \mathrm{mV}\right.$, dissolved $\mathrm{O}_{2}=40$ to $\left.50 \mu \mathrm{M}\right)$ growth of $C$. acetobutylicum was completely halted. Provided the bacterial density was sufficient ( $>0.3 \mathrm{mg}$. dry wt $/ \mathrm{ml}$.), the culture rapidly made itself anaerobic as soon as the flow of air was stopped; the $E_{\mathrm{h}}$ then quickly returned to about $-400 \mathrm{mV}$. In contrast, controlled aeration that raised the $E_{\mathrm{h}}$ of the culture to $+30 \mathrm{mV}$ did not affect growth of the organism so long as the concentration of dissolved $\mathrm{O}_{2}$ was below the sensitivity limit of the oxygen electrode (i.e. $<\mathrm{I} \mu \mathrm{M}$ ).

To determine whether it was $(a)$ the dissolved $\mathrm{O}_{2}$, or $(b)$ the elevated $E_{\mathrm{h}}$ that caused cessation of growth under aerobic conditions, artificial electron acceptors were used in place of 
$\mathrm{O}_{2}$ to poise the culture at $E_{\mathrm{h}}$ values more positive than $+50 \mathrm{mV}$. Using potassium ferricyanide, $E_{\mathrm{h}}$ of $+370 \mathrm{mV}$ could be maintained in an anaerobic culture of Clostridium acetobutylicum. The rates of: (i) growth, (ii) consumption of glucose and (iii) production of acetate, butyrate and pyruvate, all continued unchanged at this very high $E_{\mathrm{h}}$ so long as anaerobic conditions were maintained. Yet growth stopped immediately the ferricyanidecontaining culture was made aerobic (dissolved $\mathrm{O}_{2}, 40 \mu \mathrm{M}$ ), even though there was no change in the culture $E_{\mathrm{h}}$.

By intermittently adding dithiothreitol to an oxygenated culture of Clostridium acetobutylicum, we were able to poise its $E_{\mathrm{h}}$ at $-50 \mathrm{mV}$ while maintaining a positive free oxygen tension in the culture $\left(40 \mu \mathrm{M} \mathrm{O}_{2}\right)$. No growth occurred under these conditions, again indicating that the free $\mathrm{O}_{2}$ in the medium (rather than the culture $E_{\mathrm{h}}$ ) was the crucial factor in causing growth inhibition.

\section{Effects of hydrogen peroxide}

Hydrogen peroxide (I $\mathrm{mM}$ ) increased the $E_{\mathrm{h}}$ of an anaerobic culture of Clostridium acetobutylicum from $-345 \mathrm{mV}$ to $+\mathrm{I}$ I $5 \mathrm{mV}$ and halted growth of the organism. When, after $\mathrm{I} h$. exposure to hydrogen peroxide this was removed by addition of catalase and flushing with argon, the culture took about $3 \frac{1}{2} \mathrm{~h}$. to resume growth. During this lag period the organisms neither consumed glucose nor excreted acetate and butyrate. Prior to the addition of $\mathrm{H}_{2} \mathrm{O}_{2}$, the mean generation time was $94 \mathrm{~min}$. When growth resumed after removal of the $\mathrm{H}_{2} \mathrm{O}_{2}$ the mean generation time was $100 \mathrm{~min}$., so that there was little or no loss of viability during the intervening $\mathrm{I} h$. exposure to $\mathrm{I} m \mathrm{mM}_{2} \mathrm{H}_{2} \mathrm{O}_{2}$. Lesser concentrations of $\mathrm{H}_{2} \mathrm{O}_{2}$ which caused the culture $E_{\mathrm{h}}$ to rise no higher than o $\mathrm{mV}$, had no noticeable effect on growth and were ultimately destroyed, probably by interaction with pyruvate and other reducing components of the medium (Grunberg-Manago, Szulmajster \& Delavier, I952; Mallin \& Seeley, I958). No $\mathrm{H}_{2} \mathrm{O}_{2}$ production was detectable in either aerobic or aerated cultures of $C$. acetobutylicum, and addition of catalase (demonstrably still active at the end of the experiment) did not enable the organism to grow under aerobic conditions.

\section{Effects of oxygen}

Behaviour of cultures of Clostridium acetobutylicum kept (i) anaerobic, (ii) aerated or (iii) aerobic. Our observations on the degree of aeration required to produce a measurable concentration of free $\mathrm{O}_{2}$ in a rapidly growing culture of Clostridium acetobutylicum allowed us to distinguish between three experimental cultural conditions (Table I) which we designated as (i) anaerobic, (ii) aerated and (iii) aerobic.

Clostridium acetobutylicum grew as well under aerated as under its 'normal' anaerobic conditions (Fig. I). The rates of glucose utilization and of acetate and butyrate production

\section{Table I. Definition of (i) anaerobic, (ii) aerated and (iii) aerobic conditions in cultures of Clostridium acetobutylicum}

The organism was grown in glucose + casein hydrolysate + vitamins and salts medium (Methods) maintained throughout at $35^{\circ}$ and at $\mathrm{pH} 6.8$ to 7.0 .

$\begin{array}{lccc}\text { Culture conditions } & \begin{array}{c}\text { Concentration of } \\ \text { dissolved } \mathrm{O}_{2} \\ (\mu \mathrm{M})\end{array} & \begin{array}{c}E_{\mathrm{b}} \\ (\mathrm{mV})\end{array} & \begin{array}{c}\text { Rate of growth } \\ \text { (mean generation } \\ \text { time in min.) }\end{array} \\ \text { Anaerobic } & \mathrm{Nil} & -370 \text { to }-400 & 80 \\ \text { Aerated } & <\mathrm{I} & -50 \text { to }-10 & 90 \\ \text { Aerobic } & 40 \text { to } 60 & +\mathrm{I} 00 \text { to }+\mathrm{I} 50 & \infty\end{array}$


were also very similar under these two growth conditions (Table 2). No acetone or butanol was produced in either culture since a $\mathrm{pH}$ value of approximately 7 was maintained throughout. Protein, DNA and RNA were synthesized in normal proportions under both anaerobic and aerated conditions and little pyruvate was excreted into the medium (Table 2). The

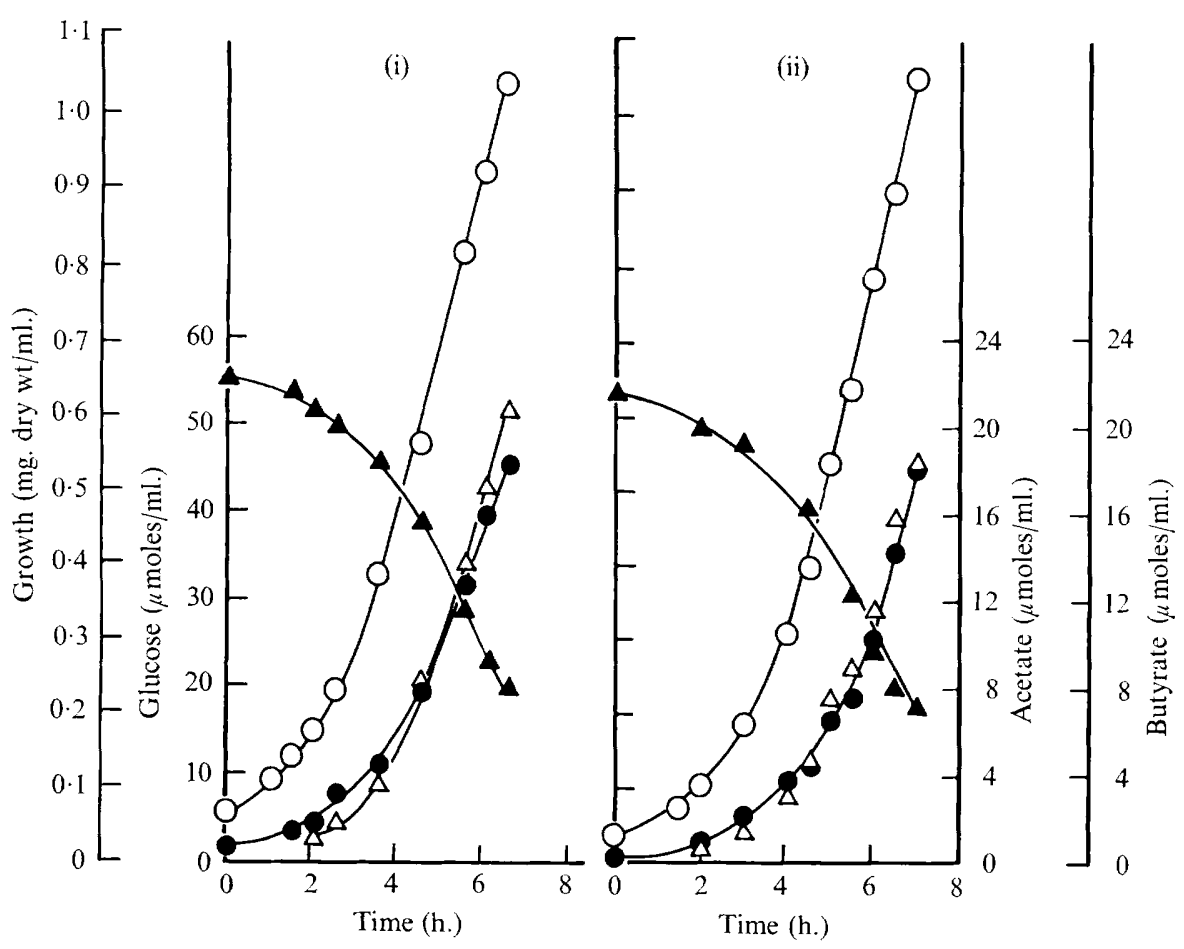

Fig. I. Growth of Clostridium acetobutylicum under (i) anaerobic and (ii) aerated conditions (see Table 1). $\bigcirc$, Growth; $\boldsymbol{\Delta}$, glucose in medium; $\triangle$, acetate in medium; $\mathbf{O}$, butyrate in medium.

Table 2. Fermentation and growth by Clostridium acetobutylicum when maintained under different culture conditions

\begin{tabular}{|c|c|c|c|c|c|c|}
\hline \multirow{2}{*}{$\begin{array}{l}\text { Culture } \\
\text { conditions }\end{array}$} & $\begin{array}{l}{ }^{*} \text { Glucose } \\
\text { utilization }\end{array}$ & $\begin{array}{c}\text { *Acetate } \\
\text { production }\end{array}$ & $\begin{array}{l}* \text { Butyrate } \\
\text { production }\end{array}$ & $\begin{array}{l}\text { *Pyruvate } \\
\text { production }\end{array}$ & \multirow{2}{*}{$\begin{array}{l}\text { Molar growth } \\
\text { yield (g. dry wt } \\
\text { organisms/ } \\
\text { mole glucose } \\
\text { consumed) }\end{array}$} & \multirow{2}{*}{$\begin{array}{l}\text { †Moles of } \\
\text { ATP pro- } \\
\text { duced/mole } \\
\text { glucose } \\
\text { utilized }\end{array}$} \\
\hline & \multicolumn{4}{|c|}{ ( $\mu$ moles $/ \mathrm{h} . / \mathrm{mg}$. dry wt organisms) } & & \\
\hline Anaerobic & I I $\cdot 2$ & $6 \cdot 5$ & 8 . & 0.3 & $29 \cdot 8$ & $2 \cdot 9$ \\
\hline Aerated & I I $\cdot 2$ & $7^{\circ}$ & $7^{\circ}$ & 0.3 & $29 \cdot 8$ & $2 \cdot 9$ \\
\hline Aerobic & 3.9 & $6 \cdot 8$ & Nil & $I \cdot 2$ & Nil growth & - \\
\hline
\end{tabular}

* These are instantaneous rates obtained from the slopes of the respective curves (Fig. I \& 2) at culture densities of approx. $0.7 \mathrm{mg}$. dry wt $/ \mathrm{ml}$.

$\uparrow$ Assuming that $Y_{\text {ATP }}=10 \cdot 3$ (Forrest, 1969).

molar growth yields of the organism obtained in the two sets of conditions were also identical and, assuming a value of $Y_{\mathrm{ATP}}$ of 10.3 (Forrest, 1969), represented the formation of 2.9 moles ATP/mole glucose utilized.

In contrast, aerobic conditions halted growth (Fig. 2). Glucose continued to be consumed at some 30 to $40 \%$ of the anaerobic rate, yet no butyrate was produced, extra acetate (per 
mole of glucose used) being formed in its place and a greater quantity of pyruvate being excreted (Table 2). When the aerobic culture was returned to the anaerobic state, the rate of glucose consumption swiftly returned to its anaerobic value and production of butyrate immediately recommenced (Fig. 2). Since aerobic conditions were not immediately lethal to Clostridium acetobutylicum it was of interest to determine whether $(a)$ increasing the concentration of dissolved oxygen during the aerobic phase, or $(b)$ prolonging the aerobic phase,

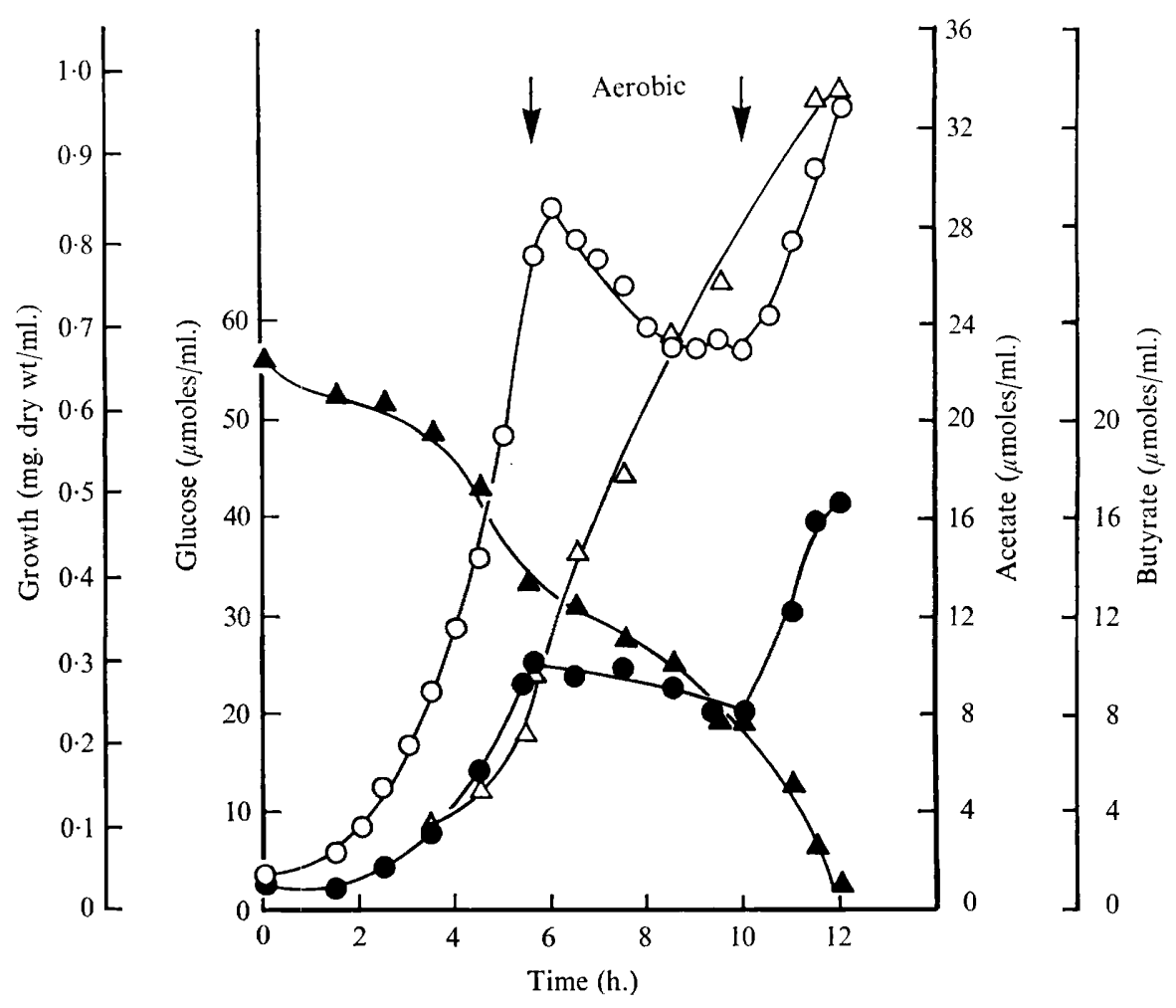

Fig. 2. Effects of aerobic conditions on growth and fermentation of Clostridium acetobutylicum. $\mathrm{O}$, Growth; $\boldsymbol{\Delta}$, glucose in medium; $\triangle$, acetate in medium; $\boldsymbol{\bullet}$, butyrate in medium. The culture, initially growing anaerobically, was maintained under aerobic conditions for the period indicated. At the end of this time anaerobiosis was re-established.

had any marked effect on the growth rate when the culture was subsequently returned to anaerobic conditions (see Fig. 2). Following exposure to oxygen (40 to $60 \mu \mathrm{M}$ ) for periods of up to $6 \mathrm{~h}$. the terminal anaerobic growth rate was decreased by only 15 to $20 \%$. No greater decrease in final anaerobic growth rate followed exposure to $150 \mu \mathrm{M}$-oxygen for $3 \mathrm{~h}$. In each case growth was exponential in both its initial and terminal anaerobic phases.

Excretion of pyruvate into the growth medium was markedly enhanced in the aerobic situation (Table 2) and continued at this increased rate when the aerobic culture was returned to its former anaerobic state. Coincident with the stoppage of growth, net synthesis of DNA, RNA and protein were halted. During the aerobic phase, while the DNA content of the organisms remained unchanged, the RNA content slightly decreased (Fig. 3). Synthesis of DNA, RNA and protein in their normal proportions resumed as soon as anaerobic conditions were re-established. 
Electron-microscopic comparison of stained thin sections of organisms taken from aerated and aerobic conditions, with similar sections prepared from anaerobically growing organisms, failed to reveal any gross cytological change that could be attributed to exposure of the organisms to oxygen.

In common with other saccharolytic Clostridium species (Hobson \& Nasr, 195I), Clostridium acetobutylicum synthesized considerable quantities of a starch-like polymer (granulose) which was accumulated intracellularly. This material was assayable as glucose following acid hydrolysis of the washed organisms (Methods). In anaerobic cultures the granulose content of the organisms, which was high in the inoculum (some $30 \%$ of the dry $\mathrm{wt}$ ), fell quite rapidly to approximately $20 \%$ of the dry wt and remained at this level during exponential growth. Under aerated conditions the granulose content of the organisms fell

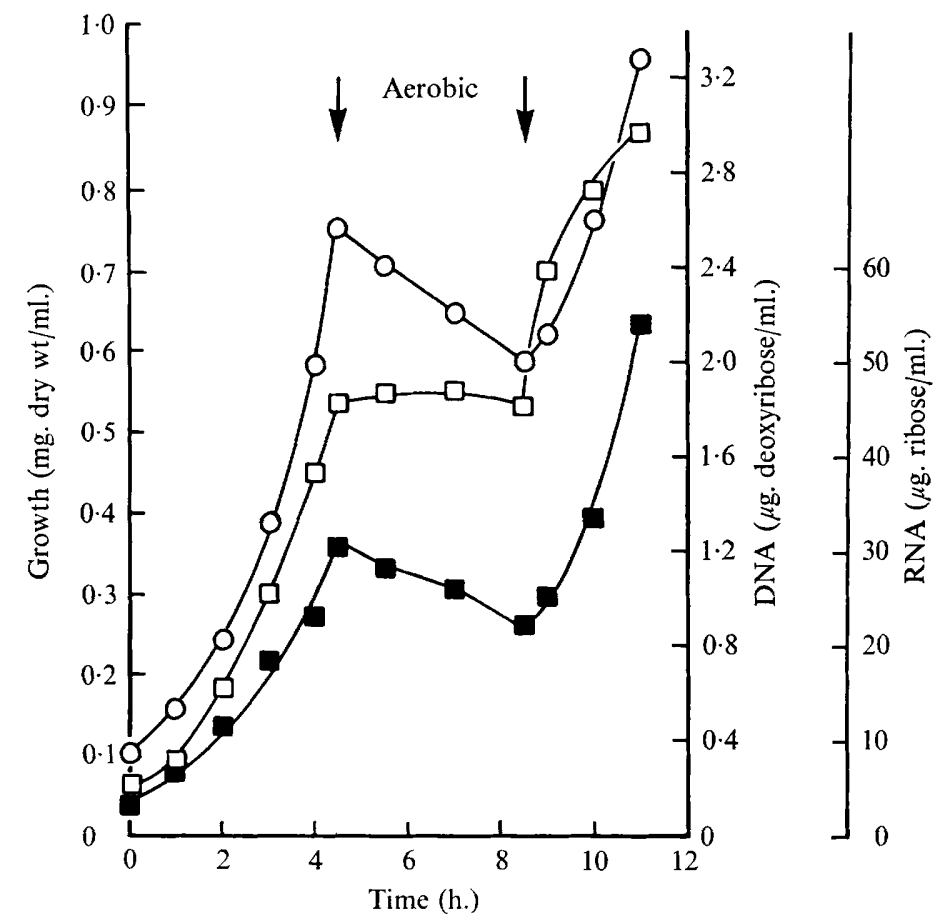

Fig. 3. Nil net synthesis of nucleic acids by Clostridium acetobutylicum while maintained under aerobic conditions. An anaerobic culture was made aerobic for the period indicated and then returned to the anaerobic state. $\bigcirc$, Growth; $\square$, DNA; $\square$, total RNA.

slowly but progressively to a value of about $15 \%$ of the total dry wt of the organism. Under aerobic conditions the granulose content of the organisms dropped sharply from an initial 25 to $10 \%$ of the dry wt over the $3 \mathrm{~h}$. during which aerobic conditions were maintained. Resynthesis of granulose commenced once anaerobic conditions were re-established.

Oxygenation and the 'energy charge content' of Clostridium acetobutylicum. One of the most striking and immediate effects of establishing aerobic conditions in a culture of Clostridium acetobutylicum was the precipitate decrease in the ATP content of the organisms (Fig. 4). Simultaneous assay of ADP (Methods) showed that the decrease in ATP was accompanied by an equal increase in the bacterial content of ADP. For example, in one experiment when an anaerobic culture containing $3 \cdot 7$ nmole ATP and $2 \cdot 4 \mathrm{nmole}$ ADP/mg. 
dry wt of organisms was made aerobic, the ATP content decreased to $\mathrm{I} \cdot 2 \mathrm{nmole} / \mathrm{mg}$. dry wt whilst the ADP content rose to $4.7 \mathrm{nmole} / \mathrm{mg}$. dry wt. Re-establishment of anaerobic conditions immediately caused the ATP and ADP concentrations to revert to $3 \cdot 2 \mathrm{nmole} / \mathrm{mg}$. dry wt and $2 \cdot 9$ nmole/mg. dry wt, respectively.

When growth of Clostridium acetobutylicum was halted by means other than excessive oxygenation, e.g. by deprivation of required amino acid(s), treatment with diamide or with metronidazole, the intracellular content of ATP did not fall even though glucose utilization was curtailed (Table 3).

Table 3. Growth inhibition of Clostridium acetobutylicum and its effects on the rate of glucose utilization and the intracellular concentration of ATP

\begin{tabular}{|c|c|c|c|}
\hline Cause of growth inhibition & $\begin{array}{c}E_{\mathrm{h}} \\
(\mathrm{mV})\end{array}$ & $\begin{array}{l}\text { * Rate of glucose } \\
\text { utilization }(\mu \text { moles } / \mathrm{h} . / \\
\text { mg. dry wt })\end{array}$ & $\begin{array}{c}\text { †Intracellular } \\
\text { ATP content } \\
\text { (nmoles } / \text { mg. dry wt) }\end{array}$ \\
\hline Nil & -370 to -400 & II $\cdot 2$ & $3 \cdot 7$ \\
\hline Limited casein hydrolysate & -380 & $\mathrm{I} \cdot \mathrm{O}$ & $4 \cdot 2$ \\
\hline Metronidazole $(0.29 \mathrm{~mm})$ & -220 to -300 & $6 \cdot 7$ & $4 \cdot 0$ \\
\hline Diamide & +50 & $4 \cdot 7$ & $3 \cdot 2$ \\
\hline Oxygen ( 40 to $60 \mu \mathrm{M}$ ) & +100 to +150 & 3.9 & $I \cdot 2$ \\
\hline
\end{tabular}

* This was the instantaneous rate, measured at culture densities of approx. $0.45 \mathrm{mg}$. dry wt $/ \mathrm{ml}$.

$\dagger$ Assayed in organisms taken I h. after cessation of growth.

\section{Table 4. Specific activity of NADH oxidase in Clostridium acetobutylicum grown under various culture conditions}

Extracts were prepared from organisms harvested in the late exponential phase of growth of the culture (at a density of approx. I $\mathrm{mg}$. dry wt/ml.). The specific activity of $\mathrm{NADH}$ oxidase was assayed as described in Methods.

$\begin{array}{ccc}\text { Poising agent } & \begin{array}{c}E_{\mathrm{b}} \\ (\mathrm{mV})\end{array} & \begin{array}{c}\text { Specific activity of NADH } \\ \text { oxidase }(\mu \mathrm{moles} \text { NADH } \\ \text { oxidized } / \mathrm{h} . / \mathrm{mg} \text {. of protein })\end{array} \\ \text { Nil } & -400 & 12.9 \\ \text { Air } & -350 & 67.0 \\ \text { *Argon } & -250 & 16.0 \\ \text { Air } & -150 & 69.5 \\ \text { Air } & -50 & 80.0 \\ \text { Diamide } & -50 & 10.7\end{array}$

* Though not itself a poising agent, vigorous gassing with argon raised the culture $E_{\mathrm{h}}$, presumably by removing some volatile reducing component(s) of the culture, e.g. $\mathrm{H}_{2}$.

Enzyme activities in organisms subjected to oxygenation. The specific activities of a number of enzymes of the glycolytic and butyrate-producing pathways were assayed in extracts prepared from Clostridium acetobutylicum grown under anaerobic or aerated conditions or terminally maintained under aerobic conditions. No marked differences were detected save in the case of NADH oxidase. The specific activity of this enzyme was increased by exposing the growing culture to oxygen (Table 4 ). The specific activity of the enzyme in extracts from organisms grown under aerated condtions (over a range of culture $E_{\mathrm{h}}$ values from -350 to $-50 \mathrm{mV}$ ) was five to six times greater than that found in extracts prepared from anaerobically-grown organisms. This increase in NADH oxidase activity was indeed provoked by exposure of the organisms to oxygen and was not due to the coincidental rise in culture $E_{\mathrm{h}}$, for no such increase in the specific activity of NADH oxidase was obtained when diamide was used in place of oxygen to poise the growing culture at an $E_{\mathrm{h}}$ of $-50 \mathrm{mV}$ (Table 4). 


\section{DISCUSSION}

At rates of aeration just insufficient to maintain a polarographically measurable concentration of oxygen in the culture medium (i.e. aerated conditions), the rate and extent of growth of Clostridium acetobutylicum were virtually indistinguishable from those obtaining under anaerobic conditions where the culture $E_{\mathrm{h}}$ was some $300 \mathrm{mV}$ more negative. The ability of the organisms to tolerate quite dramatic changes in culture $E_{\mathrm{h}}$ was emphasized by its apparently normal growth and metabolism in a medium poised by potassium ferricyanide at an $E_{\mathrm{h}}$ of $+370 \mathrm{mV}$. This must mean that oxygen inhibits growth of $C$. acetobutylicum by some mechanism other than non-specific elevation of culture $E_{\mathrm{h}}$. The specificity of the action of oxygen was further indicated by the difference in the behaviour of two cultures of $C$. acetobutylicum poised (i) with oxygen, and (ii) with diamide, both at an $E_{\mathrm{h}}$ of +80 to +100 $\mathrm{mV}$. In the aerobic culture, growth ceased, butyrate production was halted, and pyruvate was excreted into the medium (Table 2). In the diamide-poised culture, although growth very nearly stopped, there was no excretion of pyruvate and some butyrate production continued.

The normal growth and metabolism of Clostridium acetobutylicum under aerated conditions $\left(E_{\mathrm{b}}-50 \mathrm{mV}, \mathrm{O}_{2}\right.$ concentration $\left.<\mathrm{I} \mu \mathrm{M}\right)$ means that the organism could afford to divert a considerable part of its 'reducing power' to reductive detoxification of exogenous oxygen. The dramatic increase in the NADH oxidase activity of the organisms that was provoked by aeration (Table 4 ) suggests the mechanism of this drainage of intracellular reducing power. It also suggests one function for this enzyme, possession of which enables the organism to rid its environment of limited quantities of oxygen. Yet as the rate of aeration was still further increased, the rate of consumption of NADH presumably exceeded the rate at which it could be supplied for this purpose without hazarding its other essential (e.g. biosynthetic) functions in the growing organism. Thus we ultimately observed cessation of growth and the accumulation of measurable concentrations of oxygen in the culture medium. We were surprised by the comparatively high rate of aeration that was required to establish this aerobic state in cultures of C. acetobutylicum. For example, at $35^{\circ}$ with a culture density of $0.5 \mathrm{mg}$. dry wt of organisms $/ \mathrm{ml}$. it took $>500 \mathrm{ml}$. air $/ \mathrm{min}$. $/ \mathrm{l}$. of culture to maintain a dissolved $\mathrm{O}_{2}$ concentration of $50 \mu \mathrm{m}$. Any further increase in the rate of aeration, though it raised the culture $E_{\mathrm{h}}$ and increased the concentration of dissolved oxygen, had but little additional effect either on the rate of glucose consumption, or on the viability of the organisms. That the organism was indeed suffering from deprivation of NADH under these aerobic conditions was evident from the fact that although acetate continued to be produced, no butyrate was excreted; this confirmed earlier observations by Aubel \& Perdigon (I940, 1945) with washed suspensions of $C$. saccharobutyricum. It was striking that as soon as the aerobic culture was returned to the anaerobic state, production of butyrate resumed immediately, as did synthesis of DNA, RNA and protein with resultant growth at a rate that demonstrated that the organisms had suffered no significant loss of viability during the aerobic phase of incubation (Fig. 2 to 4 ).

One of the major hypotheses put forward to explain the toxicity of oxygen to obligate anaerobes, proposes that by acting as an extremely effective electron acceptor, oxygen diverts the reducing power of the organism from its necessary biosynthetic and other functions, the primary electron donors generated by the organism (e.g. NADH and NADPH) being then consumed in the energetically unrewarding task of detoxifying oxygen (see Wimpenny, I969; Morris, I970). Our observations with Clostridium acetobutylicum confirmed that this was a real possibility, yet we could not conclude that it was the sole, or even 
the ultimately crucial, cause of the toxicity of oxygen that was expressed in the deranged metabolism of the culture kept under aerobic conditions.

An obviously important effect of oxygenation on Clostridium acetobutylicum was the immediate fall in intracellular ATP (with correlative increase in ADP). As far as is known, ATP generation during glucose fermentation in this organism is by substrate phosphorylation which accompanies (i) catabolism of glucose to pyruvate via the Embden-Meyerhof pathway, (ii) generation of acetate from pyruvate via the 'phosphoroclastic reaction' followed by the action of phosphotransacetylase and acetate kinase, and (iii) production of

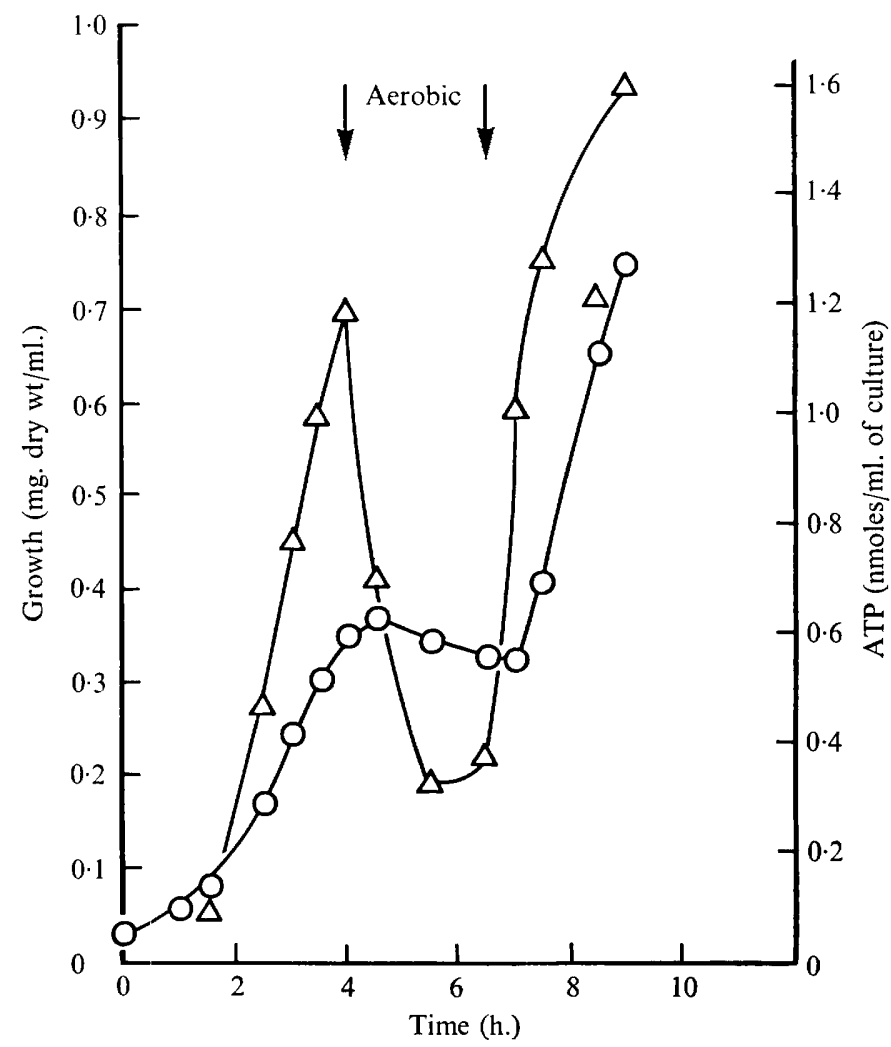

Fig. 4. Fall in intracellular concentration of ATP in Clostridium acetobutylicum exposed to aerobic conditions. A growing, anaerobic culture was made aerobic for the period shown and was then returned to its former anaerobic state. $\bigcirc$, Growth; $\triangle$, intracellular ATP.

butyrate from pyruvate - in which pathway the NADH generated by glycolysis is reoxidized and ATP is produced during the terminal conversion of butyryl CoA to butyrate via the action of phosphotransbutyrylase and butyrate kinase. The calculated yield of 2.9 moles of ATP produced per mole of glucose fermented under either anaerobic or aerated conditions (Table 2) approximately accords with this explanation of the origins of the ATP. If under aerobic conditions oxygen were merely causing accelerated reoxidation of $\mathrm{NADH}$, then butyrate production would cease and in the course of formation of the compensatory quantity of acetate there should be an increased yield of ATP per mole of glucose utilized. The cessation of growth and of the net synthesis of macromolecules that occurs under aerobic 
conditions should tend to conserve the ATP that is produced. Thus one cannot at this time conclude unequivocally that the fall in intracellular ATP that is provoked by aerobic conditions is wholly attributable to the decrease ( 60 to $70 \%)$ in the rate of glucose consumption - especially when a growth inhibitory concentration of diamide reduces glucose consumption to a similar extent but does not cause a similarly large decrease in intracellular ATP (Table 3). Aerobic conditions could perhaps enhance the rate of consumption of ATP for 'maintenance' purposes or could possibly (but less likely) promote the oxidation of glucose via an alternative pathway less productive of ATP. The mechanism whereby the aerobic condition curtails glucose consumption must evidently be investigated.

In this study we were primarily concerned with the reversible effects of oxygen on Clostridium acetobutylicum. Of course, it is possible that once the reductive defence that enables the organism to tolerate aerated conditions has been overwhelmed by the excessive rate of supply of oxygen, ingress of oxygen may cause irreversible damage to crucial enzymes and cell components (Grunberg, 1948). We have shown that such damage is not caused so rapidly as to affect viability in the short term (i.e. during the 4 to $6 \mathrm{~h}$. of exposure to aerobic conditions). In studying the longer term effects of such aerobic treatment, the major problem could well be to distinguish between specific effects of oxygenation and the more 'usual' degenerative changes suffered by resting organisms, which in this instance were maintained with an abnormally high internal $E_{\mathrm{h}}$ and an abnormally low content of ATP.

This work was supported by a grant from the Science Research Council. We wish to thank Miss Lynn Ely for skilled technical assistance, and Mr B. M. Mackey who performed the electron microscopy. R. W. O’B. is grateful to the Wellcome Trust for a Research Travel Grant.

\section{REFERENCES}

Aubel, E. \& Perdigon, E. (1940). Étude de l'action de l'oxygène sur la production de corps en $\mathrm{C}^{4}$ et en $\mathrm{C}^{2}$

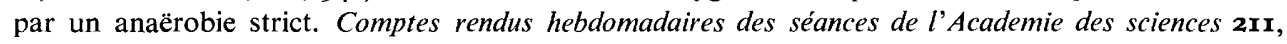
439-44I.

Aubel, E. \& Perdigon, E.(I945). Action de l'oxygène sur les anaërobies stricts. Étude de l'action de l'oxygène sur la production de corps en $\mathrm{C}_{2}$ et en $\mathrm{C}_{4}$ par Clostridium saccharobutyricum. Revue canadienne de biologie 4, 498-50I.

Bucher, T., CzoK, R., Lamprecht, W. \& Larzko, E. (1965). Pyruvate. In Methods of Enzymatic Analysis, pp. 253-262. Edited by H. U. Bergmeyer. New York and London: Academic Press.

Burton, K. (1956). A study of the conditions and mechanism of the diphenylamine reaction for the colorimetric estimation of deoxyribonucleic acid. Biochemical Journal 62, 315-323.

CRAwford, R. J. \& RAAP, R. (I963). The synthesis and reactions of $N, N^{\prime}$-dicarbalkoxy- $N, N^{\prime}$-dialkoxyhydrazines and some observations on carbalkoxylium ions. Journal of Organic Chemistry 28, 2419-2424.

ForREST, W. W. (1969). Energetic aspects of microbial growth. Symposia of the Society for General Microbiology ז9, 65-86.

Forrest, W. W. \& WALKer, D. J. (I965). Synthesis of reserve materials for endogenous metabolism in Streptococcus faecalis. Journal of Bacteriology 89, I448-1452.

Gornall, A. G., Bardawill, C. J. \& David, M. M. (I949). Determination of serum proteins by means of the biuret reaction. Journal of Biological Chemistry 177, 75I-766.

Grunberg, M. (1948). Action de l'oxygène sur les anaërobies stricts. Annales del'Institut Pasteur 74, 2 I 6-232.

Grunberg-Manago, M., Szulmajster, J. \& Delavier, C. (1952). Formation et decomposition de l'eau oxygenée par les bacteries anaërobies. Annales de l'Institut Pasteur 83, 102-117.

Hobson, P. N. \& NASR, H. (195I). An amylopectin-type polysaccharide synthesised from sucrose by Clostridium butyricum. Journal of the Chemical Society, $1855^{-1857 .}$

Mallin, A. F. \& SeEley, H. W. (1958). Some relations of hydrogen peroxide to oxygen consumption by Clostridium perfringens. Archives of Biochemistry and Biophysics 73, 306-314.

Morris, J. G. (1970). The biochemical basis of oxygen sensitivity. Journal of General Microbiology 6o, iii. 
Morris, J. G. \& O'Brien, R. W. (I97I). Oxygen and clostridia: a review. In Spore Research 197I, pp. I-38. Edited by A. N. Barker, G. W. Gould \& J. Wolf. New York and London: Academic Press. PAsTeUR, L. (I 86I). Animalcules infusoires vivant sans gaz oxygène libre et determinant les fermentations. Comptes rendus hebdomadaires des séances de l'Academie des sciences 52, 344-347.

SCHNeIDER, W. C. (I957). Determination of nucleic acid in tissues by pentose assay. In Methods in Enzymology, vol. 3, pp. 680-684. Edited by S. P. Colowick \& N. O. Kaplan. New York and London: Academic Press.

Stanley, P. E. \& Williams, S. G. (1969). Use of the liquid scintillation spectrometer for determining adenosine triphosphate by the luciferase enzyme. Analytical Biochemistry 29, 38I-392.

Sunderland, D. W. \& MerRetT, M. J. (I967). Respiration rate, adenosine diphosphate and triphosphate concentration of leaves showing necrotic local lesions following infection by tobacco mosaic virus. Physiologia Plantarum 2o, 368-372.

TelLeR, J. D. (1956). Direct, quantitative, colorimetric determination of serum or plasma glucose. Abstracts of Papers, I 30 th Meeting American Chemical Society p. $69 \mathrm{c}$.

WIMPENNY, J. W. T. (1969). Oxygen and carbon dioxide as regulators of microbial growth and metabolism. Symposia of the Society for General Microbiology 19, I6I-197. 